\title{
Section 2 of the Voting Rights Act and Judicial Elections: Application and Remedy
}

\author{
Pasquale A. Cipollone $\dagger$
}

Until recently, the question of whether $\S 2$ of the Voting Rights Act $^{1}$ applies to judicial elections seemed to have been resolved. Both the Fifth and Sixth Circuits had considered the issue and decided that the scope of $\S 2$ was broad enough to encompass judicial elections. ${ }^{2}$ The Attorney General of the United States and the Civil Rights Division of the Justice Department agreed with this conclusion. ${ }^{3}$ Most district courts that had been presented with the issue also agreed that $\S 2$ applied with full force to elected judges. ${ }^{4}$ Commentators assumed that the issue was settled. ${ }^{5}$

The Fifth Circuit resurrected the controversy with its en banc opinion in League of United Latin American Citizens ("LULAC") $v$ Clements. ${ }^{6}$ The majority held that $\S 2$ of the Act did not apply to judicial elections. ${ }^{7}$ This holding was founded on the argument that the language of $\S 2(\mathrm{~b})$, which provides that $\S 2$ is violated when protected minorities "have less opportunity than other members of

$\dagger$ B.A. 1988, Fordham University; J.D. Candidate 1991, The University of Chicago.

142 USC \& 1973 (1988). Section 2(a) provides in relevant part:

(a) No voting qualification or prerequisite to voting or standard, practice, or procedure shall be imposed or applied by any State or political subdivision in a manner which results in a denial or abridgement of the right of any citizen of the United States to vote on account of race or color ...

For the relevant text of $\S 2(\mathrm{~b})$, see text at note 27 .

3 League of United Latin American Citizens v Clements, 902 F2d 293 (5th Cir 1990), rev'd, 914 F2d 620 (5th Cir 1990) (en banc), cert granted, 111 S Ct 775 (1991); Mallory v Eyrich, 839 F2d 275 (6th Cir 1988); Chisom v Edwards, 839 F2d 1056 (5th Cir 1988).

s Chisom, 839 F2d at 1064.

4 See, for example, Williams v State Board of Elections, 696 F Supp 1563, 1565-66 (N D III 1988).

- See, for example, Note, Casting a Meaningful Ballot: Applying One-Person, OneVote to Judicial Elections Involving Racial Discrimination, 98 Yale L J 1193, 1194-95 (1989); Note, Applying Section 2 of the Voting Rights Act to Single Member Offices, 88 Mich L Rev 2199, 2200 n 8 (1990). For further commentary see 73 Judicature (Aug-Sept 1989) (special issue devoted to "The Voting Rights Act and Judicial Election").

- 914 F2d 620 (1990) (en banc). The Supreme Court heard oral argument in the case on April 22, 1991, and an opinion is expected near the end of the current Term.

7 Id at 631. 
the electorate to participate in the political process and to elect representatives of their choice,"8 simply does not extend to elected judges. ${ }^{\circ}$ The Court held that elected judges are not "representatives," and are therefore outside the scope of the statutory language.

At first blush, the holding appears to make some sense. The judicial role has traditionally been understood as quite different from the roles of legislative or executive officials. Judges are meant to be fair, unbiased, and insulated from the whims and will of the people. Judges do not "represent" people in the same way that other elected officials do. In fact, the federal courts have long held that the one-person, one-vote doctrine does not apply to judicial elections precisely because state judges "are not representatives in the same sense as are legislators or the executive."10 The majority in LULAC put great weight on this line of cases in deciding that the language of $\S 2$ did not reach judges. ${ }^{11}$ The court felt that because it was established that judges were not representatives for purposes of the one-person, one-vote doctrine, judicial elections could certainly not fall within the scope of the identical word as used in $\S 2(b)$ of the Voting Rights Act.

The strength of the court's argument, however, which after all hinges entirely on one word, begins to wane when one considers not merely the word itself, but the context in which it is found. This Comment argues that the relevant meaning of "representatives," as used in the Voting Rights Act, cannot be divined by looking solely at the word in isolation, but must be informed by the statutory structure and purpose. A full interpretive analysis will reveal that the term "representatives" in $\S 2(b)$ is far broader than the theory of representation that underlies the one-person, one-vote cases. A discussion of these uses of the same word at different levels of generality will establish that while judges have been exempted from the one person, one vote doctrine, the broad language of $\S 2$ nonetheless covers judicial elections.

After establishing that $\S 2$ applies to judges, this Comment addresses the problem of formulating the proper remedy for a judicial districting scheme that has been held to violate $\S 2$. Unique difficulties are presented by the remedial phase of judicial election

See text at note 27 for the full text of $\S 2(b)$.

${ }^{9}$ LULAC, 914 F2d at 625-27.

10 Wells v Edwards, 347 F Supp 453, 455 (1972), quoting Stokes v Forston, 234 F Supp 575, 577 (N D Ga 1964), aff'd, 409 US 1095 (1973).

11 914 F2d at $624-29$. 
cases under the Act. In fact, counter-textual interpretations of $\S 2$ that exclude judges seem to be results-oriented approaches aimed at avoiding the remedial problems presented by $\S 2$ 's application to judicial elections. Section III of this Comment analyzes the usual remedy adopted in $\S 2$ cases and argues that the typical "safe minority subdistrict" plan creates difficult problems of its own by greatly aggravating the already substantial costs of selecting judges by popular election. Section III concludes that perhaps the best "remedy" in these cases is for the states to choose to return to an appointive system of judicial selection. If designed and implemented properly, the appointment remedy will serve the purposes of $\S 2$ and result in a more effective state judiciary.

\section{The Voting Rights Act}

A discussion of $\S 2$ 's applicability to the judiciary must be founded on an understanding of the structure and purpose of the original statutory scheme, as well as the various subsequent amendments. This Section first discusses the structure of the original Act. Next, it analyzes the vote dilution decisions of the Supreme Court and the role of the Voting Rights Act in those decisions. Then it outlines the 1982 congressional amendments to $\S 2$ that are the subject of the current controversy involving the Act's application to judges. Finally, the Section surveys the cases that deal with the issue of applying $\S 2$ to judicial elections.

\section{A. The Structure of the Act}

Congress passed the original Voting Rights Act in $1965,{ }^{12}$ pursuant to $\S 2$ of the Fifteenth Amendment, ${ }^{13}$ and amended the Act in 1970,1975 , and $1982 .{ }^{14}$ The original Act implemented several mechanisms aimed at eliminating persistent discrimination in voting. Perhaps most importantly, $\S 4$ of the Act prohibited the use of literacy tests and other devices or requirements that had been used primarily to prevent blacks from voting. ${ }^{15}$ The use of such devices

\footnotetext{
12 Pub L No 89-110, 79 Stat 437 (1965).

1s The Fifteenth Amendment provides:

Section 1: The right of citizens of the United States to vote shall not be denied or abridged by the United States or by any state on account of race, color, or previous condition of involuntary servitude.

Section 2: The Congress shall have the power to enforce this article by appropriate legislation.

14 Pub L No 91-285, 84 Stat 314 (1970); Pub L No 94-73, 86 Stat 402 (1975); Pub L No 97-205, 96 Stat 134 (1982).

${ }^{1 s} 42$ USC \& $1973 \mathrm{~b}$.
} 
was immediately suspended in any political subdivision that maintained such tests or devices as of November 1, 1964, and in which less than fifty percent of the voting population was registered to vote on that date or in which less than fifty percent of voting-age persons voted in the 1964 presidential election.

In addition, political subdivisions exhibiting these characteristics ("covered jurisdictions") were subject to the preclearance provisions of $\S 5$, which required that any changes in voting practices or procedures be submitted to either the United States District Court for the District of Columbia or the Attorney General for review. ${ }^{16}$ The Act also authorized the Attorney General to use federal observers and examiners in covered jurisdictions when necessary. ${ }^{17}$ The Act provided a "bailout" procedure by which political subdivisions could remove themselves from the coverage of the "triggered" provisions of the Voting Rights Act. ${ }^{18}$

In contrast to the provisions that applied only to covered jurisdictions, $\S 2$ of the 1965 Act contained a general prohibition against discriminatory voting practices that applied to the entire nation. ${ }^{19}$ As originally enacted, $\S 2$ was viewed as "an uncontroversial provision in proposed legislation whose other provisions engendered protracted disputes." 20 Section 2 merely elaborated on the language of the Fifteenth Amendment and "was intended to have an effect no different from that of the Fifteenth Amendment itself." 21

\section{B. The Racial Vote Dilution Cases and the Voting Rights Act}

During the 1970s, the Supreme Court began dealing specifically with the issue of racial yote dilution. Plaintiffs in the vote dilution cases challenged electoral schemes under the Fourteenth and Fifteenth Amendments and under $\S 2$ of the Voting Rights Act. These cases evaluated certain electoral devices, such as atlarge electoral systems and multimember voting districts, that satisfied the Equal Protection Clause's requirement of substantial

1642 USC § $1973 \mathrm{c}$.

17 Section 6, 42 USC § 1973d.

18 Section 4(a), 42 USC $\$ 1973 \mathrm{~b}(\mathrm{a})$.

18 Pub L No 89-110, 79 Stat 437 (1965). The original § 2 provided that: "No voting qualification or prerequisite to voting, or standard, practice, or procedure shall be imposed or applied by any State or political subdivision to deny or abridge the right of any citizen of the United States to vote on account of race or color ...."

${ }^{20}$ Mobile $v$ Bolden, 446 US 55, 61 (1980).

21 Id at 60-61. 
equality of population among districts, but were alleged to unlawfully dilute the voting power of minority groups.

The Supreme Court vote dilution decisions hinged primarily on the issue of whether the Constitution or $\S 2$ of the Act required a showing of intentional discrimination, or if it was sufficient that the scheme had discriminatory "results." There was some initial confusion regarding the proper standard of proof. In White $v$ Regester ${ }^{22}$ for example, the Court seemed to implement a discriminatory results test, rather than requiring strict proof of discriminatory intent. In Mobile $v$ Bolden, ${ }^{23}$ however, the Supreme Court made clear the standard of proof for racial vote dilution violations of the Constitution and $\S 2$. The Court held that the Fourteenth and Fifteenth Amendments, as well as $\S 2$, required a showing of discriminatory purpose by those who developed or operated the voting system at issue. ${ }^{24}$ This holding led Congress to amend $\S 2$ in 1982.

Congress rejected the intent test in its amendments to $\S 2{ }^{25}$ The battle over the amendments dealt principally with the issue of which standard of proof should be adopted. Both the House and the Senate ultimately chose the "results" test. The Senate Judiciary Committee's version of $\S 2$, engineered primarily by Senator Robert Dole, came to be known as the "Dole Compromise." The Senate bill preserved the "results" standard adopted in the House bill, but added $\S 2(\mathrm{~b})$ in order to clarify the scope and application of the new test.

Section $2(b)$ codified the test for vote dilution originally articulated by the Supreme Court in White v Regester. In White, the Court held that to establish the existence of prohibited vote dilution, plaintiffs would have to prove, based on the "totality of the circumstances," that "the political processes leading to nomination and election were not equally open to participation by the group in question-that its members had less opportunity than did other residents in the district to participate in the political processes and to elect legislators of their choice." ${ }^{26}$ The Senate committee incorporated this language directly into $\S 2(\mathrm{~b})$, substituting the word "representatives" for "legislators." Congress ultimately passed the

\footnotetext{
21412 US 755 (1973).

23446 US 55 (1980).

s4 Id at 62,66 .

15 Pub L No 97-205, 96 Stat 134 (1982).

36412 US at $769,776$.
} 
Senate version of $\S 2(b)$, which allowed proof of a violation of $\S 2$ upon a showing that

the political processes leading to nomination or election in the State or political subdivision are not equally open to participation by members of a class of citizens protected by subsection (a) of this section in that its members have less opportunity than other members of the electorate to participate in the political process and to elect representatives of their choice. ${ }^{27}$

Thornburg $v$ Gingles ${ }^{28}$ presented the Supreme Court with the task of interpreting and applying the newly enacted results test. In Gingles, the Court reviewed the Senate Report, which listed a variety of factors typically relevant to a $\$ 2$ claim, including the history of discrimination in the state and the extent to which minority candidates have been elected. ${ }^{29}$ The Court stressed, however, that this list was not exhaustive, nor was a plaintiff required to prove any particular number of these factors. According to the Court, the hallmark of a $\S 2$ violation is that "a bloc voting majority must usually be able to defeat candidates supported by a politically cohesive, geographically insular minority group." ${ }^{30}$

\section{Case Law on Judicial Elections and Section 2}

Since 1982, the federal courts have used the results test to strike down several districting plans that resulted in racial vote dilution. ${ }^{31}$ Recently, the courts have addressed $\S 2$ suits attacking

${ }^{27} 42$ USC \& $1973 \mathrm{~b}$.

${ }^{28} 478$ US 30 (1986).

${ }^{28}$ Id at 44-45. The Court stated that the Senate Report required an analysis of the following factors in $\$ 2$ cases:

... the history of voting related discrimination in the State or political subdivision; the extent to which voting in the elections of the state or political subdivision is racially polarized; the extent to which the state or political subdivision has used voting practices or procedures that tend to enhance the opportunity for discrimination against the minority group, such as unusually large election districts, majority vote requirements, and prohibitions against bullet voting; the exclusion of members of the minority group from the candidate slating process; the extent to which minority group members bear the effects of past discrimination in areas such as education, employment, and health, which hinder their ability to participate effectively in the political process; the use of overt or subtle racial appeals in political campaigns; and the extent to which members of the minority group have been elected to public office in the jurisdiction.

Id. In addition, "evidence demonstrating that elected officials are unresponsive to the particularized needs of the members of the minority group and the policy underlying the state's . . contested practice or structure may have probative value." Id.

so Id at 48-49 (emphasis in original).

31 See, for example, East Jefferson Coalition for Leadership and Development $v$ Parish of Jefferson, 703 F Supp 28 (E D La 1989), affd, 926 F2d 487 (5th Cir 1991); Citizens for a Better Gretna $v$ City of Gretna, 834 F2d 496 (5th Cir 1987), reh'g den, 849 F2d 1471 (1988), 
judicial election schemes. ${ }^{32}$ Most courts have ruled that the language of $\S 2$ covers judicial elections. Three courts, however, have disagreed. Before they were reversed by their respective circuits, two district courts held that $\S 2$ did not apply to judges because judges are not "representatives." More recently, in LULAC, the Fifth Circuit, sitting en banc and reversing two Fifth Circuit panel decisions, ${ }^{34}$ also held $\S 2$ inapplicable to judicial elections. ${ }^{35}$ The majority opinion reopened what had been a settled issue in every circuit that had considered the question, including the Fifth.

Before $L U L A C$, the two most prominent cases on point were Chisom $v$ Edwards ${ }^{36}$ and Mallory $v$ Eyrich ${ }^{37}$ In both cases the district courts ruled that $\S 2$ did not apply to judges, because judges could not be included within any possible definition of the statutory term "representatives." The district courts relied primarily on the one person, one vote cases ${ }^{38}$ arguing that since that doctrine did not apply to judges, $\S 2$ likewise could not apply. ${ }^{39}$

The Fifth and Sixth Circuits both reversed. Both courts argued that reliance on only one word obfuscated the issue, and that an examination of the structure and history of the Voting Rights Act as well as its practical application was essential to the interpretive question. According to the courts of appeals, the plain language of the Act, the policies behind the enactment of $\S 2$, pertinent legislative history, and previous interpretations of $\S 5$ of the Act all supported applying $\S 2$ to judicial elections. ${ }^{40}$

The Fifth Circuit's original panel opinion in LULAC agreed with the Sixth Circuit and reaffirmed Chisom, applying $\S 2$ to

cert denied, 109 S Ct 3213 (1989); Campos v City of Baytown, Texas, 840 F2d 1240 (5th Cir 1988).

32 Plaintiffs have challenged state judicial election systems in several states, mostly in the South. See, for example, Clark $v$ Edwards, 725 F Supp 285 (M D La 1988); Chisom v Edwards, 659 F Supp 183 (E D La 1988), rev'd, 839 F2d 1056 (5th Cir 1988), cert denied as Roemer v Chisom, 109 S Ct 390 (1988); Brooks v State Board of Elections, 1989 US Dist LEXIS 16357 (S D Ga); Williams v State Board of Elections, 696 F Supp 1563 (N D III 1988); Southern Christian Leadership Conference of Alabama v State of Alabama, $714 \mathrm{~F}$ Supp 511 (M D Ala 1988); Mallory v Eyrich, 666 F Supp 1060, rev'd, 839 F2d 275 (6th Cir 1988); Martin v Mabus, 700 F Supp 327 (S D Miss 1988).

33 Chisom, 659 F Supp at 186; Mallory, 666 F Supp at 1064.

s4 Chisom, 839 F2d 1056; LULAC, 902 F2d 293.

35 LULAC, 914 F2d 620.

s8 839 F2d 1056.

37839 F2d 275.

ss The one person, one vote doctrine is discussed in Section II.C.

30 Chisom, 659 F Supp at 185-86; Mallory, 666 F Supp at 1063-64.

to Mallory, 839 F2d at 278-81; Chisom, 839 F2d at 1059-64. 
judges. ${ }^{41}$ On rehearing en banc, however, the Fifth Circuit reversed the panel determinations in both Chisom and LULAC. The en banc majority's reasoning tracked that of the Chisom and Mallory district courts, with particular emphasis on the one person, one vote line of cases." The court argued that those cases are "not only instructive as to the meaning of 'representatives' and thus as to the scope of Section 2, [they are] . . . dispositive of the precise issue of the scope of Section 2's applicability in this case."43 A close look at the one person, one vote doctrine will establish that this conclusion is not supported by the case law. An examination of the statutory arguments alone, however, is enough to support the conclusion that $\S 2$ applies to judges.

\section{Section 2's Application to Judicial Elections}

Ultimately, the question of whether $\S 2$ applies to judicial elections concerns the proper level of generality to ascribe to the word "representatives" as used in that section. Those who argue for the exemption of judicial elections from $\S 2$ assign a narrow level of meaning to the term, reading "representatives" to exclude judges. Several factors, including statutory purpose, context, and structure, contradict such a restrictive interpretation and support defining the term at a broader level of generality.

It is impossible to resolve the debate over the meaning of the word "representatives" in the abstract. The interpretive task is to divine the relevant and most plausible level of meaning, given context and purpose. In some sense, albeit not in the same sense as a legislator, judges can be considered representatives. ${ }^{44}$ The position that $\S 2$ excludes judges ultimately rests on the idea that "to sug-

41 The Chisom case dealt with a challenge to state appellate judicial districts in Texas. In $L U L A C$, the plaintiffs challenged the at-large election of state trial judges under $\S 2$ (b). The majority concluded that $\$ 2$ applied, but relied on the distinction between single-member and multimember offices to ultimately hold that $\S 2(b)$ did not apply to trial judges, since that office is exercised exclusively by one individual. This distinction is discussed in text at notes $102-05$.

${ }^{2}$ LULAC, 914 F2d at 627.

43 Id.

4. In the words of Judge Higginbotham:

It is true that judges do not carry the views of a certain group of people into a larger governmental body, attempting to sway that body toward decisions favorable to their constituency. That is not the necessary role of a representative. We extol the virtues of the jury in criminal cases-the jury is said to be the representatives of the people .... The examples can be multiplied, but the point is plain. The conclusion that the word 'representative' has the singular meaning of legislator is nothing more than an effort to substitute judicial will for that of Congress.

Id at 636 (Higginbotham concurring) (footnotes and citations omitted; emphasis in original). 
gest that Congress chose 'representatives' with the intent of including judges is roughly on a par with suggesting that the term night may, in a given circumstance, properly be read to include day."45 "Night" and "day," of course, are polar opposites; they are mutually exclusive. But this is not the relationship between the term "representatives" as used in $\S 2$ and the elected judiciary. At some level, however broad, the former includes the latter.

This Section demonstrates that the word "representatives" was meant in its general and not restricted sense. Statutory purpose and structure as well as the legislative history support this conclusion. The Section then responds to the argument that the one person, one vote cases require exempting judges from $\S 2$.

\section{A. The Structure and Purpose of the Voting Rights Act}

The purpose of $\S 2$ is to protect the right of minorities to participate equally in the election process. This right is implicated whenever there is an election, whether it involves legislators or judges. Nothing in the language of the Voting Rights Act suggests that the importance of the right to vote depends on the duties of the particular official being elected. Nor is there anything inherent in the nature of the judiciary that should exempt these elections from the guarantees afforded minorities by $\S 2$.

An examination of the broader structure of the Act- $\S 5$ in particular-also supports the conclusion that $\S 2$ applies to the judiciary. Section 5 requires covered jurisdictions to preclear changes in "any voting qualification or prerequisite to voting, or standard, practice, or procedure ...." The preclearance review must ensure that the proposed change "does not have the purpose and will not have the effect of denying or abridging the right to vote on account of race." ${ }^{47}$ In Allen v State Board of Elections, the Supreme Court rejected a narrow construction of $\S 5$ and held that "[t]he legislative history on the whole supports the view that Congress intended to reach any state enactment which altered the election law of a covered State in even a minor way." ${ }^{48}$ The Court interpreted $\S 5$ in order to give the Act "the broadest possible scope."49

The broad scope of the $\S 5$ preclearance provision has been extended to the judiciary. In 1985, a three-judge court in Haith $v$

\footnotetext{
45 LULAC, 914 F2d at 629 (emphasis in original).

46 USC § $1973(\mathrm{c})$.

47 Id.

48393 US 544, 566 (1969).

40 Id at 567.
} 
Martin" $^{\text {50 }}$ held that "the fact that an election law deals with the election of members of the judiciary does not remove it from the ambit of section 5." 51 This holding was affirmed by the Supreme Court. ${ }^{52}$ The defendants in Haith based their arguments, as do the current $\S 2$ defendants, on the line of cases that found one person, one vote inapplicable to judges. The Haith court, however, rejected the distinction, made in the one person, one vote cases, ${ }^{53}$

between those in the legislative branch of government who represent their constituents in the making of laws and those in the judicial branch who do not represent a constituency but, rather, interpret the law. Discounting the interesting jurisprudential arguments arising from such an attempted distinction it is quite clear that no such distinction can be attributed to the Act. ${ }^{54}$

The court then cited the broad language of $\S 2(a)$ and stated: "[a]s can be seen the Act applies to all voting without any limitation as to who, or what, is the object of the vote." jected the argument that the one person, one vote cases shed light on the proper interpretation of the Voting Rights Act. Further, by holding $\S 5$ applicable to judges, the decision supports applying $\S 2$ to judicial elections as well.

The Haith decision requires extending $\S 2$ to judges in order to avoid creating an anomaly in the statute. If judges are deemed outside the scope of $\S 2$, then an election scheme that would be subject to $\S 5$ preclearance if presented as a change could not be challenged under $\S 2$, even if it resulted in minority vote dilution. ${ }^{66}$ The nearly identical language of the two sections and the complementary nature of their purposes suggest that both apply to judicial elections.

Further, the fact that $\S 5$ applies only to covered jurisdictions while $\S 2$ applies universally does not support the conclusion that $\S 2$ need not cover judges even though $\$ 5$ does. This only high-

${ }^{\text {so }} 618$ F Supp 410 (E D NC 1985).

51 618 F Supp at 413. See also Kirksey v Allain, 635 F Supp 347 (S D Miss 1986).

82477 US 901 (1986).

ss See Section II.C.

34 618 F Supp at 413 (citation omitted).

ss Id (emphasis in original).

80 "Such a result would be totally inconsistent with the broad remedial purpose of the Act. Moreover, section 5 and section 2, virtually companion sections, operate in tandem to prohibit discriminatory practices in voting, whether those practices originate in the past, present, or future." Chisom, 839 F2d at 1064. See also LULAC, 914 F2d at 645 (Higginbotham concurring). 
lights the inconsistency that such an interpretation would create. First, as described above, in covered jurisdictions changes to judicial election schemes would have to be precleared, but existing districts could not be challenged under $\S 2$ even if they resulted in vote dilution. In addition, jurisdictions not covered by $\S 5$ could operate judicial election plans that diluted minority votes, and could also implement changes that resulted in increased dilution, as long as plaintiff's could not prove discriminatory intent.

Alternatively, one could argue that since the test to be applied under $\S 5$ is different from the $\S 2$ results test, ${ }^{57}$ one can apply to the judiciary at the same time that the other does not. But any such distinction is irrelevant to the question of whether $\S 2$ applies to judges, as $\S 5$ does. The subtle difference between the two tests does not affect their coextensive coverage of every other kind of election, and there is no relevant characteristic of the judiciary that would argue in favor of making one or the other test inapplicable. Such arguments were rejected when they were made to restrict the scope of $\S 5$ from covering the judiciary, and they must be rejected again with regard to $\S 2$ for the same reasons. ${ }^{58}$

\section{B. The Legislative History}

The language, purpose, and structure of the statute, standing alone, are enough to support $\S 2$ 's application to judicial elections. On matters involving the Voting Rights Act in general, and the amended $\S 2$ in particular, however, the Supreme Court has relied heavily on legislative history. ${ }^{59}$ This legislative history is consistent with the conclusion that $\S 2$ applies to judges. ${ }^{60}$

s7 Under the $\S 5$ test, preclearance will be denied to those changes in voting practices, however minor, that have the purpose or the effect of denying or abridging the right to vote because of race. The Supreme Court has construed the effects test of $\S 5$ as prohibiting those changes that would have a retrogressive effect on the voting strength of minorities. Beer v United States, 425 US 130, 141 (1976). This "retrogression test" would strike down only those voting changes that have a negative effect on the ability of minority groups to participate in the political process and elect their candidates to office. Id. The $\$ 5$ test, of course, applies only to the change being implemented and not to the entire election scheme. Section 2's results test, on the other hand, applies to the entire existing electoral structure.

ss LULAC, 914 F2d at 645 (Higginbotham concurring).

s9 See, for example, Gingles, 478 US at 36; Allen, 393 US at 566-68. Thomas M. Boyd and Stephen J. Markman, The 1982 Amendments to the Voting Rights Act: A Legislative History, 40 Wash \& Lee L Rev 1347 (1983), is often cited as the definitive work on the legislative history of the 1982 Amendments.

-0 Dillard v Crenshaw County, Alabama, 831 F2d 246, 250-51 (11th Cir 1987) (Nothing in the legislative history suggests that $\S 2$ 's applicability depends on “the function performed by an elected official."). 
The text of the original $\S 2$ was quite broad and had nationwide applicability, ${ }^{61}$ and the Act defined the terms "vote" and "voting" extremely broadly. ${ }^{62}$ It seems certain that judicial elections were covered by the language of $\S 2$ as originally enacted..$^{63}$ Although the language did not mention judicial elections specifically, the text was unequivocal. ${ }^{64}$ Even in the Supreme Court's voting rights opinions, there is "no hint . . . that any state or local election, whatever the office involved, is exempted from coverage of the 1965 Act."

As discussed, in 1982 Congress changed the language of $\S 2$ (a) and added $\S 2(\mathrm{~b})$ in order to replace the "intent" interpretation of Mobile v. Bolden with a results test. Section 2(a) was amended to preclude political subdivisions from imposing any voting procedure in a manner "which results in a denial or abridgement of the right of any citizen of the United States to vote . . ." Section 2(a) otherwise retained the identical broad language it had contained prior to the amendments. Section 2(b) was added to explain how a violation of the new results test could be established. Congress took the language of $\S 2(\mathrm{~b})$ directly from the Supreme Court's White $v$ Regester opinion, merely replacing the term "legislators" with the more expansive term "representatives." This change itself supports the argument that Congress intended the scope of $\S 2(\mathrm{~b})$ 's explanation of the results test, codified in $\S 2$ (a), to parallel the all-inclusive language of $\S 2(\mathrm{a})$. If $\S 2(\mathrm{a})$ applies to judges, $\S 2(\mathrm{~b})$ must then also apply; the results test is codified in $\S 2(\mathrm{a})$ and explained in $\S 2(b)$.

61 See note 19.

B2 The terms include "all action necessary to make a vote effective in any primary, special, or general election, including, but not limited to, registration, listing pursuant to this subchapter, or other action required by law prerequisite to voting, casting a ballot, and having such ballot counted properly and included in the appropriate totals of votes cast with respect to candidates for public or party office and propositions for which votes are received in an election." Section 14, 42 USC § 1973l(c)(1).

63 In Allen, Chief Justice Warren argued that "[i]ndicative of an intention to give the Act the broadest possible scope, Congress expanded the language in the final version of $\S 2$ ...."393 US at 566-67.

6. There is further support for the broad reading of the original $\S 2$ in the Supreme Court's Mobile $v$ Bolden holding, which viewed $\S 2$ as basically tracking the Fifteenth Amendment. To say that the original $\S 2$ did not apply to judges is to implicitly suggest "that the protections of the Fifteenth Amendment do not extend to minorities whose right to vote in judicial elections is abridged. The Fifteenth Amendment applies to all elections, and Congress intended the Voting Rights Act of 1965 to apply to all elections." $L U L A C, 914$ F2d at 637 (Higginbotham concurring).

6s Mallory, 839 F2d at 278.

so 42 USC $\S 1973$ (a) (emphasis added). 
The purpose of the 1982 amendments was to make it easier to prove minority vote dilution in violation of $\S 2$, in light of Mobile $v$ Bolden's intent requirement. ${ }^{67}$ The argument that $\S 2$ excludes judges comes down to the assertion that although Congress did indeed expand the Act, it drew a statutory line exempting judges, evidenced by the word "representatives" in $\S 2(\mathrm{~b})$. The difficulty with this argument is that there is no support for the contention that the $\S 2$ amendments involved a decision by Congress to specifically exempt the judiciary from a provision that had covered it all along. There is practically no discussion of the judiciary in the history of the amendments, nor is there even the slightest hint that the judiciary would be exempt from the new, more protective language of $\S 2$. Such a suggestion would almost certainly have met with a great deal of resistance, and Congress would have thoroughly debated such a change. Silence in the record on this point supports the inference that Congress intended to continue the applicability of $\S 2$ to judicial elections. The text of the amended version was changed only to the extent necessary to incorporate the results test, and the new language can easily be read to include judges. If this language was meant to effect not one, but two large changes in the original provision, this would have been made clear in either the record or the text, but probably both. The Senate Report itself states that "Section 2 remains the major statutory prohibition of all voting rights discrimination."68

Congress used the word "representatives" interchangeably with "candidates" and "elected officials" throughout the amendment process. ${ }^{69}$ This suggests that Congress did not use "repre-

\footnotetext{
${ }^{67}$ More precisely, Congress repudiated the intent test for 3 principal reasons:

$\ldots$ it is "unnecessarily divisive because it involves charges of racism on the part of individual officials or entire communities," it places an "inordinately difficult" burden of proof on plaintiffs, and it "asks the wrong question." The "right" question, as the Report emphasizes repeatedly, is whether "as a result of the challenged practice or structure plaintiffs do not have an equal opportunity to participate in the political process and elect candidates of their choice."
}

Thornburg $v$ Gingles, 478 US 30, 44 (1985), quoting Senate Report at 36, 28 (emphasis added).

es Mallory, 839 F2d at 279, citing Voting Rights Act Amendments of 1982, S Rep No 97-417, 97th Congress, 2d Sess 30 (1982).

69 See Mallory, 839 F2d at 279-80, for an exhaustive list of such examples appearing in the record. Especially telling are the words of the author of the "Dole Compromise." Senator Dole explained:

Citizens of all races are entitled to have an equal chance of electing candidates of their choice, but if they are fairly afforded that opportunity, and lose, the law should offer no redress. 
sentatives" as a restrictive term of art intended to exclude judges, but rather to parallel the all-inclusive language of $\S 2(a)$ and reach all elected officials. The judiciary was rarely mentioned directly, but these examples only serve to indicate that it was assumed that the amended $\S 2$, like the original, would continue to cover judicial elections. For instance, Senator Orrin Hatch described the $\S 2$ term "political subdivision" as encompassing "all governmental units, including city and county councils, school boards, judicial districts, utility districts, as well as state legislatures."70

The text of $\S 2$ admits of no exception based on the function performed by the official being elected. The amended $\S 2$ grants minorities no less protection in elections than did its predecessor. The only change Congress made in 1982 was to adopt the results test. Nowhere, including in the Supreme Court's jurisprudence, is there any support for a restricted reading of the term "representatives." 11 A Congress intent on excluding judges would have done so in the language, or would at least have mentioned it in the debates.

\section{The One Person, One Vote Doctrine}

The courts that have refused to extend $\S 2$ to judicial elections argue that the word "representatives" cannot be construed to include elected judges. They point out that judges were excluded from the coverage of the one person, one vote cases because they are not representatives for purposes of that doctrine. Congress expressly restricted the scope of the results test to elections of "representatives." Because judges have been held to be outside the scope of that word for purposes of the one person, one vote rule, the argument is that Congress must have intended the same judicially determined definition when drafting $\S 2$.

The weakness in the argument is that it imports a definition from a line of cases that is legally and logically distinct from. the

[T] he standard is whether the political processes are equally "open" in that members of a protected class have the same opportunity as others to participate in the political process and to elect candidates of their choice.

LULAC, 914 F2d at 639 (Higginbotham concurring), quoting S Rep No 97-417 at 193 (court's emphasis).

${ }^{70} \mathrm{~S}$ Rep No $97-417$ at 151 (emphasis added). The congressional record of the 1982 amendments also contains various references to judges, in the form of statistics presented to Congress to indicate the progress made under the Act since 1965.

${ }^{71}$ Gingles, 478 US at 44 (question under the results test is whether, "as a result of the challenged practice or structure plaintiffs do not have an equal opportunity to participate in the political processes and to elect candidates of their choice") (quoting S Rep No 97-417 at 28) (emphasis added). 
$\S 2$ protection against minority vote dilution. This Section first examines the one person, one vote cases on their own terms, and then demonstrates that the conclusion that judges are not "representatives" for purposes of those cases does not demand the same conclusion in the context of $\S 2$.

1. The one person, one vote doctrine and judicial elections.

The one person, one vote doctrine requires that electoral districts be drawn so that they are substantially equal in population. ${ }^{72}$ In Reynolds $v$ Sims, the Court held that districts that differed dramatically in population violated the Equal Protection Clause of the Fourteenth Amendment. ${ }^{73}$ The idea behind these cases was that representatives must be elected by similar numbers of voters if each individual voter is to have an equal voice in government. During the 1960s and 1970s, the Court defined the scope of the one person, one vote rule by determining the elections to which it would apply. In Hadley $v$ Junior College District of Metropolitan Kansas City, the Court specifically articulated the broad sweep of the one person, one vote rule: "as a general rule, whenever a state or local government decides to select persons by popular election to perform governmental functions, [the one person, one vote doctrine applies]." 74

Courts have consistently held, however, that the one person, one vote doctrine does not extend to judicial elections, even after the seemingly all-inclusive language in Hadley. ${ }^{75}$ In fact, in Wells $v$ $E d w a r d s,^{76}$ the Supreme Court affirmed without opinion a district court's determination that the principle of one person, one vote was not applicable to the judiciary. Justice White, joined by Justices Douglas and Marshall, vigorously dissented, arguing that the broad language of Hadley did not create an exception for judicial elections. ${ }^{77}$ Nevertheless, in Wells, the Court implicitly endorsed

72 For the evolution of the doctrine, see Colegrove v Green, 328 US 549 (1946); Gomillion v Lightfoot, 364 US 339 (1960); Baker v Carr, 369 US 186 (1962); Gray v Sanders, 372 US 368 (1963); Wesberry $v$ Sanders, 376 US 1 (1964). The rule was formally articulated in Reynolds $v$ Sims, 377 US 533 (1964).

37 US at 568.

" 397 US 50, 56 (1970).

78 See, for example, Buchanan v Gilligan, 349 F Supp 569, 571 (N D Ohio 1972); Holshouser v Scott, 335 F Supp 928, 932 (M D NC 1971), aff'd mem, 409 US 807 (1972).

76347 F Supp 453, 454 (M D La 1972), aff'd mem, 409 US 1095 (1973).

77 The district court had stated that it was "not unaware of the broad language of $\mathrm{Had}$ ley, ... but [was] of the opinion that [this] exception ... was contemplated by the Court in Hadley." 347 F Supp at 454. 
the view that the apportionment cases had been founded on a theory of representation that did not apply to the judiciary ${ }^{78}$

These decisions focused on the distinction between judges and other elected officials. The courts. recognized that the one person, one vote cases were predicated on a restricted notion of representation that excluded the judiciary. ${ }^{79}$ The foundational assumption of the one person, one vote doctrine is that the elected official at issue must act as the voice or advocate of a particular constituency. The logic of the doctrine depends on the idea of representative as partisan advocate. Only if an elected official is to be the voice of her constituency does it make sense to say that each official must, as a constitutional matter, be elected by substantially equal numbers of voters. If this were not the rule, it would be possible to give certain individual voters less "representation," in the sense of having less of a "voice" in democratic government, by assigning them fewer representatives.

It is precisely this underlying logic that led the courts to hold the doctrine inapplicable to the judiciary. The doctrine is based on a representative as a "voice" or "advocate." This concept of representation does not apply to judges, because elected judges are simply not meant to be advocates, partisans, or protectors of the special interests of a particular constituency. ${ }^{80}$ The fact of election does not alter the judicial role. Judges need not be elected by equal numbers of people because they do not function as legislators or executives. They owe no allegiance to a particular group of voters. They owe only the duty to decide cases fairly and to interpret the laws without bias. Because judges are not representatives within the restrictive rationale of the one person, one vote cases, election districts with equal populations are not constitutionally required to maintain the legitimacy of these elections. Judges, then, are not

78 The underlying logic of these decisions illustrates that "[t]he primary purpose of one-man, one-vote apportionment is to make sure that each official member of an elected body speaks for approximately the same number of constituents. . . . Thus, the rationale behind the one-man, one-vote principle, which evolved out of efforts to preserve a truly representative form of government, is simply not relevant to the makeup of the judiciary." Id at 455 .

${ }^{70}$ See Stokes $v$ Forston, 234 F Supp 575, 577 (N D Ga 1964) (per curiam). See also Buchanan v Rhodes, 249, F Supp 860, 865 (N D Ohio 1966), appeal dismissed, 385 US 3 (1966), judgment vacated, 400 F2d 882 (6th Cir 1968).

80. Stokes, 234 F Supp at 577 (function of judges "is to administer the law, not to espouse the cause of a particular constituency"); Rhodes, 249 F Supp at 865 ("[W]e must: recognize one glaring distinction between the functions of legislators and the functions of jurists. Judges do not represent people, they serve people."). • 
"representatives" in the sense that underlies and justifies the one person, one vote rule.

There are other rational and important considerations that can be taken into account by a state distributing its judges. These concerns were another driving force behind the exemption of judges from the one person, one vote rule. ${ }^{81}$ Case load, for instance, determined by the volume and nature of litigation arising in various parts of the state, is often unrelated to population. ${ }^{82}$ An area with fewer people but more litigation will need more judges. Thus, as a practical matter, rigid application of the rule to judicial elections makes less sense than in other contexts; other criteria besides population are relevant to judicial apportionment.

2. One person, one vote and racial vote dilution.

Whether a judge is meant to function as a "representative" in the traditional sense is a critical question. It was precisely this issue that the courts in the one person, one vote cases thought they were confronting, and it was for this reason that they held the doctrine inapplicable to the judiciary. Those courts believed that the requirement of equal population apportionment was founded on a traditional concept of representation that by definition excluded judges.

The Voting Rights Act is not so narrow. It addresses the concern of racial discrimination in voting and, more specifically, racial vote dilution. This concern is just as relevant to judicial elections as to any other. The original Act used broad, intrusive, and radical measures to meet the serious problem of discrimination in voting. The amendments continue this tradition. The 1982 amendments make it easier to challenge an election scheme by making proof of resulting dilution sufficient to establish a violation of the provision. There was no reason for Congress to single out judicial elections from this provision and there is no real evidence that it did so. The use of the word "representatives," by all indications, was meant in its general and not restricted sense. It was not meant to invoke a grand debate over the nature of the judiciary. The conceptually distinct nature of the one person, one vote and the racial vote dilution doctrines, as well as the case law developing the one person, one vote doctrine, support this conclusion.

${ }^{-1}$ See New York State Ass'n of Trial Lawyers v Rockefeller, 267 F Supp 148, 154 (S D NY 1967).

82 Id. 
a) Two separate requirements. The courts that exempt judges from $\S 2$ do so primarily because the one person, one vote doctrine exempts judges. For example, the en banc majority in $L U$ $L A C$ viewed the one person, one vote cases as controlling. ${ }^{83}$ In fact, the court felt that minority vote dilution depended on the idea of individual vote dilution, "[f]or it is the assumption of substantial equality (achieved through the guarantee of one-person, one-vote) that underlies the concept of minority vote dilution."

This purported dependence is mistaken, however; it conflates two separate requirements. The one person, one vote doctrine is a constitutional requirement under the Equal Protection Clause of the Fourteenth Amendment. If districts are not substantially equal in population, equal protection is violated. There is no need to go further; the plaintiff is entitled to a remedy. However, the fact that a particular election scheme comports with the one person, one vote rule does not end the inquiry. Even schemes that pass the first test must then be analyzed to ensure that they were not conceived and do not operate to dilute minority votes.

Protection against minority vote dilution, on the other hand, is both constitutional and statutory, guaranteed by the Fourteenth Amendment, the Fifteenth Amendment, and the Voting Rights Act. The Constitution forbids racial vote dilution that is the result of discriminatory intent, while $\S 2$ reaches such dilution whenever it occurs, regardless of the intent of those who devised or operate the election scheme at issue. The fact that the one person, one vote requirement and the minority dilution prohibition both derive from the Fourteenth Amendment (the former in whole and the latter in part) does not make the second doctrine dependent on the first. The requirement of equal population across districts and racial vote dilution are independent principles. The doctrines are certainly related in some sense, but they cannot be said to depend entirely or even substantially on each other. ${ }^{85}$

\footnotetext{
ss Judge Gee wrote that the "Wells holding-that the one-person, one-vote rule does not apply to the judiciary-leads inexorably to the conclusion that judicial elections cannot be attacked along lines that their processes result in unintentional dilution of the voting strength of minority members." 914 F2d at 627.

${ }^{84}$ Id at 628.

8s See id at 643 (Higginbotham concurring) (Noting that the two doctrines "measure equality on quite different planes. [One person, one vote] is facially neutral in the matter of race; indeed compliance may adversely affect black voting power. [Racial vote dilution] rests on core concerns of the Civil War amendments-submerging of minority voting strength by the combined force of election methods and bigotry.").
} 
This distinction is recognized in many court opinions dealing with voting rights in general and this issue in particular. ${ }^{86}$ In fact, the Fifth Circuit itself has held as a general matter, in Voter Information $v$ City of Baton Rouge, that even though the one person, one vote doctrine exempted the judiciary, the distinct minority vote dilution concept of the Fourteenth and Fifteenth Amendments applied to judges with full force. ${ }^{87}$ In Chisom, a Fifth Circuit panel cited this holding as support for its conclusion that the racial dilution concept embodied in $\S 2$ likewise extended to the judiciary.$^{88}$ Both the Voter Information holding and its logical extension in Chisom recognize the distinction between the requirement of numerically equal voting districts and protection against racial vote dilution.

It is universally accepted that a condition of racial vote dilution created by a judicial election scheme, which can be proven to be caused by intentional discrimination, will be found to violate the Constitution. This assumes, of course, that the condition of racial vote dilution can be identified as a preliminary matter, even in absence of the separate requirement of one person, one vote. The condition of racial dilution, once found to exist, must then be shown to be the product of discriminatory intent under Mobile $v$ Bolden.

But proving the actual existence of the dilution is independent of the process of proving that the existing dilution is caused by discriminatory intent, as opposed to resulting merely from the structure of the electoral scheme itself, regardless of the motives of those who created it or who currently operate it. Holding that intentional vote dilution in judicial elections clearly violates the Constitution compels the conclusion that such a condition is identifiable even though judicial districting plans are exempt from the requirement of the one person, one vote rule. The preliminary application of the equal population principle, then, is in no sense a

s8 See, for example, Mallory, 839 F2d at 277-78; Chisom, 839 F2d at 1061. 1980):

87 Voter Information Project, Inc. v City of Baton Rouge, 612 F2d 208, 211 (5th Cir

To hold that a system designed to dilute the voting strength of black citizens and prevent the election of blacks as Judges is immune from attack would be to ignore both the language and purpose of the Fourteenth and Fifteenth Amendments. The Supreme Court has frequently recognized that election schemes not otherwise subject to attack may be unconstitutional when designed and operated to discriminate against racial minorities.

so 839 F2d at 1061 ("It is difficult, if not impossible, for this Court to conceive of Congress, in an express attempt to expand the coverage of the Voting Rights Act, to have in fact amended the Act in a manner affording minorities less protection from racial discrimination than that provided by the Constitution. ...."). 
prerequisite for the existence and identification of racial vote dilution.

Once this distinction is grasped, it becomes clear that the exemption of judges from the one person, one vote doctrine does not prevent applying the vote dilution prohibition embodied in $\S 2$ to judicial elections. If it is possible to ascertain the existence of a condition of racial dilution as a preliminary step in the proof of a constitutional violation, then surely it must also be possible to identify the same phenomenon in a $\S 2$ case. The only difference in the $\S 2$ case is that the resulting minority vote dilution, once iden: tified, is itself sufficient to establish a violation of the Voting Rights Act. Under the Constitution, the existence of racial vote dilution is only evidence of the discriminatory intent required to prove a constitutional violation. However, the process of identifying the actual condition known as racial vote dilution, and the nature of this phenomenon, are the same under both the Constitution and the Voting Rights Act. It therefore cannot be said that the requirement of one person, one vote is in any sense a "benchmark" or a "baseline" without which it would be impossible to detect the existence of racial vote dilution resulting from either intentional discrimination or from some other characteristic or combination of circumstances created by a particular districting scheme. ${ }^{88}$

b) Judges; the one person, one vote precedents; and LULAC. Given the precedents and the logic underlying them, it is difficult to see why the majority in LULAC confuses the distinction between one person, one vote and racial vote dilution. In fact, the $L U L A C$ majority goes so far as to say that it is a conceptual impossibility to test for racial vote dilution where one person, one vote does not apply because, the court claims, without the assumption of substantial equality of population, "there exists no yard-

${ }^{89}$ This issue arose when $L U L A C$ was argued before the Supreme Court. Some of the Justices suggested that without the application of the one person, one vote doctrine, there is no standard for deciding whether a minority group's votes have been diluted. Justice Scalia, for instance, asked: "You don't know what watered beer is unless you know what beer is.... You need a standard. How do I know when a person of a different race has gotten less when I don't have a base line?" Linda Greenhouse, High Court Hears Arguments on Election of Judges, NY Times A17 (Apr 23, 1991). Solicitor General Starr correctly responded: "The base line is set forth in the statute. .. . That is the congressionally mandated baseline." Id. See note 29. 
stick by which to measure either the 'correct' magnitude of minority voting strength or the degree of minority vote dilution."

The court's conflation of these two separate requirements leads it seemingly to contradict itself. The court explicitly reaffirms the irrebuttable position that intentional minority vote dilution in a judicial election violates the Constitution, ${ }^{91}$ yet it also holds that the $\S 2$ results test has no application in the absence of the one person, one vote doctrine. ${ }^{92}$ Surely the court would not have concluded that the original $\S 2$, whose broad language was held to be identical to the dictates of the Constitution, could not apply to judges because one person, one vote did not apply. It is difficult to see how the amended $\S 2$ can be held not to apply to the judiciary for precisely the same reason. To say that minority vote dilution analysis cannot be entertained whenever one person, one vote has been held not to apply makes no sense, for the same reasons, under both the original and the amended text of $\S 2$.

Indeed, the cases exempting judges from the one person, one vote doctrine explicitly recognize the distinction between equality of population and racial vote dilution. For example, in Holshouser $v$ Scott, the court expressly qualified its decision by stating that the plaintiff "does not contend that there is discrimination in either the nominating process or the election process ....W We are unable to find discrimination among voters or unequal weighing of votes which would amount to arbitrary or capricious action or invidious distinctions." 93 The definition of "representatives" announced in these cases excluded judges, but the logic behind the definition belies the assertion that it applies in the Voting Rights Act context. The one person, one vote doctrine requires that election districts be substantially equal in population because of the inherent arbitrariness of large population disparities in legislative districts. Because of the pure representative function performed by legislators, for instance, each vote must count equally, and any significant departure from equality in population is inherently arbitrary. Judges, on the other hand, fall outside the one person, one vote doctrine because they do not fall within this pure definition of representation. Population disparities in judicial districts, therefore, are not inherently arbitrary-there are rational factors other

\footnotetext{
90 914 F2d at 628.

11 Id at $625 \mathrm{n} 6$.

92 Id at 627-28.

9s 335 F Supp 928, 933 (M D NC 1971), aff'd mem, 409 US 807 (1972).
} 
than population that a jurisdiction may consider when apportioning judges. ${ }^{94}$

The factors important in proving a $\$ 2$ violation, on the other hand, are as relevant to judicial elections as to any other election. These factors, which are listed in the Senate Report and are viewed as authoritative by the courts, ${ }^{95}$ include such issues as the extent to which voting in elections in the state has been racially polarized, the extent to which minorities have been elected to office, whether minorities have been denied access to the candidate slating process, whether political campaigns have been characterized by subtle or overt racial appeals, and the extent to which the state uses voting practices or procedures that may enhance the opportunity for racial discrimination. ${ }^{96}$ These indicia of racial discrimination or vote dilution apply equally to all elections, including judicial elections. As the Fifth Circuit has stated, "the various 'one man one vote' cases involving Judges make clear that they do not involve claims of race discrimination as such."

Thus, the fact that judges do not "represent" constituents in the traditional sense of the word is enough to exempt them from coverage under the one person, one vote principle given the logical foundations, purpose, and practical reality of that doctrine. So, it can be true that judges need not be elected from districts of substantially equal populations. It does not follow, however, that a state can draw districts that systematically dilute the votes of protected racial minority groups in judicial elections. Nor does it follow that these minority groups can do nothing about racial vote dilution unless they can prove the "intent" necessary to meet the requisite constitutional standard. This was precisely the reason Congress amended $\S 2$ in 1982. Reliance on the one person, one vote line of cases in interpreting $\S 2$ is misguided because the doctrines of population equality and racial vote dilution are conceptually different. ${ }^{98}$ There is nothing about the character of a judicial office that should allow states to dilute the votes of racial minority groups in the election of judges, as opposed to other candidates. 81-82.

9. See Gilligan, 349 F Supp at 571; Rhodes, 249 F Supp at 865 . See also text at notes

${ }^{85}$ Gingles, 478 US at $36-38,43$ n 7 . See note 29.

${ }^{-6} \mathrm{~S}$ Rep No 97-417 at 28-29.

or Voter Information Project, 612 F2d at 211.

${ }^{88}$ See Southern Christian Leadership Conference v Siegelman, 714 F Supp 511, 520 (M D Ala 1989). 


\section{Remedy in Section 2 Judicial Election Cases}

Closely tied to the question of whether $\S 2$ applies to judicial elections is the issue of how, if at all, courts should remedy violations in the judicial context. This Section demonstrates that the remedial questions presented by $\S 2$, while difficult, are not insoluble. The Section surveys the traditional remedy adopted in $\S 2$ cases involving the judiciary-the safe minority subdistrict-and argues that, while legitimate, it greatly increases the problems that exist when a state chooses its judges by popular election. These increased costs of judicial elections outweigh their benefits, both as a general matter and as a mechanism for achieving diversity on the state bench. Because courts generally allow states themselves to suggest a remedial plan when a $\S 2$ violation is found, this Section concludes by arguing that the best remedy in these cases is for the state to choose to return to an appointed judiciary. If implemented properly, this remedy will achieve all of the goals of the Voting Rights Act and avoid the "injustices" that courts find in other proposed remedies.

\section{A. The Remedial Dilemma}

The word "representatives" in $\S 2$ should be read broadly to include the office of elected judge. Courts faced with this question know that if they give $\S 2$ its proper scope, they will have to apply the results test for vote dilution to judicial districting plans. More importantly, these courts will be faced with the difficult task of crafting remedies for those judicial voting plans that violate $\S 2$. The practical and jurisprudential difficulties involved in interfering with a state's method of selecting judges seems to be the critical (but unspoken) factor behind those decisions excluding judges from the scope of $\S 2$. Courts recognize that extending $\S 2$ to judges may only "further polarize the voting blocs which currently exist, and will almost certainly result in the removal from the bench of a number of decent, fair, and competent state judges with many years of dedicated service." possibility that no fair, reasonable, and equitable remedy can ever be fashioned to redress whatever section 2 violations may exist" in these cases. ${ }^{100}$ The courts fear that extending $\S 2$ to judges may remedy one injustice while creating another. ${ }^{101}$

\footnotetext{
92 Id at 521.

$100 \mathrm{Id}$.

101 Id.
} 
These remedial difficulties seem to influence the courts' substantive analysis on whether $\S 2$ applies to judges. In fact, some opinions even hold $\S 2$ applicable to the state judiciary as a preliminary matter, but then rely on other interpretive devices to avoid the remedial problem. For example, in his original panel majority opinion in $L U L A C$ and his concurrence in the en banc rehearing of the case, Judge Higginbotham argued that while § 2 applied to judges, it did not apply to all judges. Specifically, he would apply the Act to judges who sit on a collegial court, but not to trial judges who sit alone. In effect, Higginbotham's opinions, while paying lip service to the strong statutory arguments in favor of applying $\S 2$ to the judiciary, proceeded to carve out an exception that as a practical matter excludes much of the judiciary from $\S 2$.

The opinions rely on a distinction between multimember and single-member offices. first articulated in Butts $v$ City of New York. ${ }^{102}$ The concept of the single-member office is founded on the realization that there cannot be remediable vote dilution where subdistricts in which a minority is dominant are physically impossible to draw. ${ }^{103}$ When an office is filled by one person, a mayor or governor for instance, there can be no partial "share" of the office as there can be in the case of a multimember body. ${ }^{104}$

Judge Higginbotham took this distinction and recharacterized its rationale. $\mathrm{He}$ argued that the relevant aspect of a single-member office is not that it is held by one person, so that subdistricts are impossible to draw. Instead, the important characteristic is that one individual exercises the full authority of the office. ${ }^{105} \mathrm{Be}$ cause trial judges make decisions on their own, Judge Higginbotham characterized them as single-member offices. The fact that there are many trial judges and that subdistricts could easily be drawn was thought to be irrelevant.

Higginbotham's concurrence in LULAC, like the en banc majority's opinion, relies on untenable reasoning to avoid applying $\S 2$. This avoidance seems to be based on a recognition of the difficult remedial question presented when $\S 2$ is applied to the judiciary. Whatever the difficulties in crafting a remedy, however, it must be recognized that the question of the applicability of $\S 2$ is

102779 F2d 141, 148 (2d Cir 1985). See also Dillard, 831 F2d at 251. For a discussion of the distinction, see Pamela S. Karlan, Undoing the Right Thing: Single-Member Offices and the Voting Rights Act, 77 Va L Rev 1 (1991); Note, 88 Mich L Rev 2199 (cited in note 5).

103 Siegelman, 714 F Supp at 519.

${ }^{104}$ Butts, 779 F2d at 148.

${ }^{105}$ LULAC, 914 F2d at 648-49 (Higginbotham concurring). 
logically distinct and should not be tainted by a results-oriented fear of remedial problems. Courts that exclude the judiciary from $\S 2$-whether on a wholesale basis or by misuse of the single-member concept as a "deus ex machina"-do damage to the statutory structure of the Voting Rights Act.

\section{B. Traditional Districting Remedies Under Section 2}

Once a $\S 2$ violation is established, the remedial plan almost always involves the complicated redrawing of the district lines in the challenged election. In $\S 2$ cases, there is a general requirement, premised on federalism concerns, that defendant jurisdictions receive a chance to develop their own remedy, to which the court should defer if it cures the violation. ${ }^{106}$ If the defendant fails to provide an adequate plan, courts usually fashion a remedy that carves up the state into smaller districts, each electing one member of the governmental body. One or some of these "subdistricts" will contain a majority of a particular minority group sufficient to ensure that the group will be able to elect a representative of its choice. The theory is that while under the old scheme it was possible to submerge all of the minority votes into the majority such that the majority could override the choices of the minority and elect all of the members of a governmental body, the new plan allows the minority to elect at least one member. For example, in a scheme found to dilute the votes of blacks, at least one of the new districts will consist of a black majority that will now be able to elect a representative of its choice.

A few courts have approved remedies for judicial apportionment plans found to violate $\S 2$. One of the first cases to deal with the $\S 2$ remedial issue in the context of the judiciary was Martin $v$ Mabus. ${ }^{107}$ The basic feature of the plan adopted by the court, the "safe" minority subdistrict, was similar to $\S 2$ remedies for legislative districts. ${ }^{108}$ The central focus of the remedy was the require-

${ }_{108}$ See, for example, Wise $v$ Lipscomb, 437 US 535, 540 (1978) (plurality opinion); Karlan, 77 Va L Rev at 12-13 (cited in note 102); Comment, Vote Dilution, Discriminatory Results, and Proportional Representation: What is the Appropriate Remedy for a Violation of Section 2 of the Voting Rights Act?, 32 UCLA L Rev 1203, 1258-61 (1985).

${ }_{107} 700 \mathrm{~F}$ Supp 327 (S D Miss 1988). The court appointed an expert to devise a remedial plan only after the defendant jurisdiction proposed an unacceptable remedy that retained at-large, multimember districts. Id at 330-31.

${ }^{108}$ Illinois recently adopted a similar plan for judicial districting. William Grady, Justice to Take on Local Flavor: County to Elect Resident Judges, Chicago Tribune $\S 2$ at 1 (Feb 18, 1991). The salient feature of the scheme is the drawing of judicial "subcircuits," some of which will be safe minority districts. Legislators have not yet approved precise dis- 
ment that each judicial district should have at least one subdistrict with a black majority population of sixty percent. ${ }^{108}$ The court found, however, that applying these policies to judicial as opposed to legislative elections created some unique problems.

The Martin court focused first on the overall characteristics of the proposed districts. It recognized that one person, one vote did not apply, so equal population across districts was not required. Nevertheless, the remedy sought to minimize population variances among subdistricts as a matter of "general equity."110 Furthermore, the traditional redistricting factors of contiguity, compactness, community of interest, natural boundaries, and preservation of existing lines were considered. The court found, however, that the communities of interest are different in judicial than in legislative elections. Because severe campaign restrictions are placed on candidates in judicial elections, attorneys will be known only by their home communities, rather than by their entire districts. The court was therefore hesitant to split towns and counties. ${ }^{111}$ The court also recognized that the value of incumbency was greater in judicial than in legislative elections. It refrained, however, from intentionally favoring sitting judges, relying instead on the voters' ability to favor future incumbents in the new subdistricts. ${ }^{112}$

Under the plan, judges would be elected from single-member subdistricts within each district, but would have jurisdiction over the entire district. The court refused to implement a subdistrict residency requirement for two reasons. First, residency is appropriate for legislators who should be close to their constituents, but this is not true of judicial officers. Judges, unlike legislators, do not serve their subdistricts; they serve the district as a whole by applying the law "in an unbiased manner rather than representing their supporters." $" 113$ Second, a residency requirement was difficult because of the low number (or perhaps absence) of statutorily quali-

trict lines, but the new subcircuits are projected to include four predominantly black districts, four predominantly suburban districts, four "ethnic Democratic" districts, and a Hispanic district. The plan will be phased in gradually, so that sitting judges will not be removed from the bench immediately. The goal of the plan is to diversify the state judiciary and the chief means employed is the safe minority district.

${ }^{109}$ There was a disagreement over what size the percentage majority should be in the black subdistricts. It centered on whether registration and turnout rates should be accounted for. The court held that a sixty percent population would allow blacks in the subdistrict to elect a candidate of their choice. Martin, 700 F Supp at 333.

120 Id at 332.

121 Id at 332-33.

112 Id.

113 Id. 
fied candidates in each subdistrict. The plan, therefore, required residency only in the district as a whole. The defining characteristic of the remedy, though, was the safe minority subdistrict.

\section{Costs of Traditional Districting Remedies}

The safe subdistrict remedy imposes substantial costs on states that choose judges by election. In short, these remedies create the impression among voters and judges that the judges are in some sense the voice of their constituencies. Some would argue that this is precisely the result intended by the Voting Rights Act-that the conclusion that judges are "representatives" is necessarily tied to the view that judges ought to be responsive to their "constituents."

This Comment rejects that view. The existence of an elected judiciary does not change the conception of the proper role of the judiciary. States that adopt an electoral system do so because of dissatisfaction with appointment, not because they intend to alter the fundamentally independent and unbiased nature of the judiciary. Unfortunately, the traditional safe subdistrict remedy compromises the independence of the judiciary.

1. The elected judiciary and the judicial function.

The argument that judges must not act as advocates for a constituency assumes a certain conception of the proper role of the judiciary. If it is to remain legitimate, the judicial power must be exercised in an unbiased manner. A partisan judiciary fighting for a particular agenda or the "rights" of a specific group is nothing less than tyrannical. Judges, to paraphrase Hamilton, can exercise neither force nor will but merely judgment. ${ }^{114}$ However, what are we to make of a judiciary selected by popular election?

The rationale for moving to an elected judiciary was not based on some idea that the traditional independent nature of the judiciary should change or that judges should "represent" constituencies that elect them in the same sense that legislators do. Rather, it was prompted by a dissatisfaction with the type of people that were being selected to serve as judges. Judicial elections were a Populist response to a concern that judges were too frequently appointed

\footnotetext{
${ }^{114}$ Federalist 78 (Hamilton), in Clinton Rossiter, ed, The Federalist Papers 464, 465 (New Am Library, 1961).
} 
from the privileged classes, and that the appointment system was not particularly designed to improve justice. ${ }^{115}$

This initial politicizing of the bench, however, met with almost immediate dissatisfaction of another sort that resulted in a series of reforms to minimize political influences on the judiciary. ${ }^{116}$ These reforms included non-partisan elections and merit selection. Merit selection was an attempt to combine the benefits and minimize the costs of both election and appointment. Under the merit plan judges are appointed (by the governor and perhaps some nonpolitical nomination commission) and occasionally stand for retention election, in which voters decide only whether the judge should remain in office. If the judge is rejected, another is appointed to fill the vacancy. ${ }^{117}$ This plan is thought to provide the benefits of knowledgeable selection of qualified jurists, the minimization of political influences, and the ability of people to exercise some control over those who would undertake the duties of this branch of government. ${ }^{118}$

Popular election provides the benefit of allowing the people to choose directly those who will exercise the judicial power. In that sense it satisfies the democratic urge to select government officials by popular vote. However, elections do not change the qualities that are important in a good judge. Elections merely change the people responsible for assessing whether and to what degree a particular candidate possesses these relevant characteristics. The democratic pedigree of elected judges is purer than that of appointed judges in the sense that the former are selected directly by the people, rather than indirectly by executives or legislators representing the people. It is precisely this characteristic, however, that gives rise to the significant costs of electing judges. These costs, it is thought, consist of the sacrificing of both the independence and quality of the state judiciary. ${ }^{119}$

\footnotetext{
118 No state had an elected judiciary at the time of the framing of the Constitution. Lower court judges were first elected in Georgia in 1812, but Mississippi was the first state to adopt a completely elected judiciary in 1832. Glenn R. Winters, Selection of Judges-An Historical Introduction, 44 Tex L Rev 1081, 1082 (1966). See also LULAC, 914 F2d at 63536 (Higginbotham concurring).

${ }_{118}$ Id at 1083. Instead of implementing reforms, some states, including Virginia and Mississippi, simply returned to appointment after unfavorable early experiences with elections.

117 Id at 1084.

${ }_{118}$ Id. Another benefit would be "the reminder to the elected judge that he is the people's servant and not their master." Id.

110 For additional discussion of the history of state judicial selection in the United States, see Harry P. Stumpf, American Judicial Politics 153-88 (Harcourt Brace Jovanovich, 1988).
} 
2. Traditional remedies and inroads into the judicial function.

The chief costs of electing the judiciary are the politicization and loss of independence that the jurisdictions selecting that method of choosing judges have sought to minimize. When judges are forced to stand for election, they are in danger of being perceived (or worse, perceiving themselves) as partisans advancing a particular agenda. In addition, judges are exposed to the compromising pressure of the political process, which interferes with the ability to decide cases fairly and objectively. Judges must solicit contributions in order to run for reelection, creating at least the appearance of or the potential for impropriety. ${ }^{120}$ More importantly, since the judge owes her job to the current majority, she is potentially affected by the wishes of that majority. This conflicts with the judge's role as protector of minorities against majority tyranny. ${ }^{121}$

The problem with the traditional "safe subdistrict" remedy is that it exacerbates the costs already associated with an elective system. Several aspects of the traditional remedy contribute to the politicization of the judiciary. First, the actual drawing of the districts will be a complicated and hotly debated issue. The complexity of the process will allow other silent agendas to come into play. In Illinois, for instance, Republican legislators strongly support the recent plan because they hope to draw suburban districts that will assure more Republican judges. ${ }^{122}$ The goal of minority representation thus can provide an effective trojan horse for political gerrymanderers. The safe subdistrict remedy also serves to further politicize the elected judiciary. Line drawing becomes a partisan fight to get more "partisan" judges. This feeds the illegitimate view of the elected judge as advocate.

Second, electing judges with statewide jurisdiction from small subdistricts increases the appearance of and potential for bias. What happens, for example, when a judge hears a case between a

${ }^{120}$ The ABA has designed provisions to limit these improprieties in judicial elections. See ABA Code of Judicial Conduct, Canon 7, reprinted in Thomas D. Morgan and Ronald D. Rotunda, 1990 Selected Statutes on Professional Responsibility 341, 353-55 (Foundation, 1990).

${ }^{221}$ For an extended analysis of the relative merits of appointment versus election, see Stumpf, American Judicial Politics at 166-78 (cited in note 119); Philip L. DuBois, From Ballot to Bench: Judicial Elections and the Quest for Accountability (Texas, 1980). For a particularly interesting historical perspective, see Lamar T. Beman, Election Versus Appointment of Judges (4 The Reference Shelf No 2) (H.W. Wilson, 1926).

${ }^{122}$ Grady, Justice to Take on Local Flavor (cited in note 108). 
prominent citizen from his subdistrict who contributes to his campaign fund and a citizen from another subdistrict who cannot even cast a ballot in the next election? The concern here is not the presence of actual biased decisions. The real problem, as in federal diversity policy, is the potential loss of popular confidence in the judicial branch. Popular belief that the courts are biased, regardless of whether they in fact are, will severely impair the effective functioning of the judiciary.

Third, the traditional remedy further magnifies bias concerns; the resulting smaller subdistricts increase the political accountability of the judiciary. Because the judge must stand before a smaller group of voters, the political pressure exerted to decide cases consistent with the views of the majority in that community is potentially much greater. Judges themselves are more likely to be influenced because it would be much easier for a particular decision to be mischaracterized, propagandized, and disseminated to a smaller electorate. Again, a judge's decision might not actually be influenced in this way, but the cost incurred is the substantially increased probability of such influence created by the increased political pressures of the new subdistricts.

Fourth, these remedial plans not only draw smaller districts, they also create "white," "black," and "Hispanic" judicial districts. This fuels the notion that judges elected from these subdistricts are advocates of their respective constituencies while on the bench. This concept is created by the two sides of the $\S 2$ coin. It protects participation and guarantees results, and these two policy concerns are difficult to separate. The suggestion is that predetermined outcomes are the best way to protect unimpaired equal participation. So the remedial goal is to give minorities more elected officials by drawing districts that will ensure this. This policy, however wise in the legislative context, has been imported into judicial districting without distinguishing the distinct role played by the judge. Such a plan massages an illegitimate conception of the judiciary into the consciousness of the populace: it perpetuates the idea that judges are partisan advocates as opposed to unbiased arbiters. It enforces the idea by injecting the politics of racial separation into the process of judicial selection-the idea that blacks and Hispanics must have their own judges and whites theirs.

While this may not be a stated goal of the remedy, it is undeniably a direct implication. This notion is further supported because it appears that it is not sufficient under the Act that black or Hispanic judges are elected to the bench. On the contrary, the Act seems to require that minority judges must be elected by minority 
districts. ${ }^{123}$ If widely accepted, this assumption could destroy the effective functioning of the judiciary, because it uses racial criteria to address the problem of race-based politics. The purported "cure," then, is simply more of the disease. It gives rise to troubling questions, because it presumes that minorities cannot get fair treatment in the courts unless there are minority judges, elected by minorities, on the bench. The implication is that the judiciary is inherently prejudiced.

But will this problem, if it indeed exists, be solved by simply diversifying the judiciary as a whole? To assure proper balance, won't cases need to be assigned by the racial makeup of the litigants, the judges, or both? Will it require "racially balanced" appeals panels? Will defendants have to be tried by judges of their own race? Once the idea of biased judges is accepted-and indeed the entire structure of the remedy feeds this idea - the seeds of the judiciary's destruction are sown. This is not to suggest that there are not legitimate reasons for promoting diversity on the bench. Rather, attempting to achieve diversity through safe subdistricting is promoting diversity for the wrong reasons: such a remedy diversifies the judiciary at the price of destroying its legitimacy.

\section{Return to Appointment}

Once a $\S 2$ violation is found, the court allows the affected jurisdiction to offer a remedial plan. The court must accept the plan if it solves the $\S 2$ problem, even if the court itself would have chosen another remedy. A state faced with this choice should remedy the problem by returning to an appointive system of judicial selection. The alternative safe subdistrict remedial plan introduces new costs into the equation that swamp any benefits previously realized from selecting judges by popular election. If implemented properly, an appointive system can achieve the legitimate policy goals of the Voting Rights Act with respect to judges, and avoid the substantial costs of any subdistrict plan. While a return to appointment raises some concerns that need to be addressed, it provides the best solution to this difficult problem.

${ }^{123}$ See The Wrong Minority, Wall St J A14 (April 29, 1991). This editorial discusses the example of Faith Johnson who was one of the first black criminal court judges in Dallas. If a current voting rights suit is successful, Judge Johnson's job will probably be dissolved as part of the remedy because she "is the 'wrong kind' of minority. She happens to be a Republican." Roland Rios, the lawyer challenging the Dallas judicial districts, claims that Judge Johnson and others like her cannot "represent" minorities since " $98 \%$ of blacks and $80 \%$ of Hispanics vote Democratic." Id. 
1. The benefits of appointment and legitimate diversity.

Appointment will prevent the difficulties presented by subdistrict remedies. It will remove the political pressure on judges created by a small, specialized electorate. Of course, appointment would not be completely free of politics, but the pressures would be far less than in popular elections. If judges are appointed for life, judicial independence will be further protected.

More importantly for purposes of $\S 2$, though, diversity can be promoted through the appointment process. There are both legitimate and illegitimate reasons for promoting diversity on the bench. It is illegitimate to desire diversity so that any particular group will have a voice or an advocate in the judiciary. This is founded on an unacceptable view of the proper role of a judge. Diversity is, however, desirable for other reasons. First, diversity increases public confidence in the objectivity and fairness of the bench. Positive public perception is essential to the efficacy of the judiciary. There is also some "role model" benefit to having minorities on the bench. Furthermore, diversity brings different perspectives to the bench, at least to the extent that race is a valid proxy for perspective. This is not to say that such candidates take judicial positions with the idea of promoting an agenda or serving a constituency. Instead, the idea is that judges will remain unbiased, but that perspective will come to bear in some way on their decisions. In any event, agreement with all of these rationales for diversity is not essential. All that is necessary is support for diversity for some reason other than a desire to transform the judiciary into a subjective, partisan institution under the control of the electorate.

Assuming that the state officials appointing judges have been elected pursuant to plans that comport with the Voting Rights Act, an appointive system indirectly preserves the $\S 2$ pedigree of judges. These decisionmakers can promote diversity by making race one among many factors considered when selecting a qualified candidate. The independence of these judges will be protected, and the potential that they will be perceived (or will perceive themselves) as advocates for a particular interest group will be minimized. If diversity is a significant concern of voters, whose voice in the legislative and executive branches has been guaranteed by $\S 2$, then it will come to bear on those officials responsible for judicial appointments. More importantly, the particular method of appointment implemented must be designed to give minorities an adequate voice in the appointment process. Changing to an appoin- 
tive system will also allow states to avoid the injustice and inefficiencies of removing qualified and experienced judges from the bench in large numbers. New judges can simply be appointed as vacancies become available.

2. Potential negative ramifications of the appointment remedy.

The remedy of appointment has its problems, of course. First, it gives rise to federalism concerns. Although the state itself "chooses" the remedy, states that have decided to select their judges by election will be "encouraged" by the courts to change to an appointive system. The choices of the states will be reversed by federal policy. In some sense, this remedy is more intrusive than a new districting plan because it does not merely modify but completely alters the selection method adopted by the state. However, because the states have the first chance at formulating a remedy, the ultimate choice remains with them. Granted, the federal policy alters the incentives inherent in the choice and counsels a move to appointment, but such a change is in no way mandatory. Federal policies often create incentives without expressly requiring states to take certain specific actions. The choice to elect judges was made in a pre- $\S 2$ world. Section 2 alters the costs and benefits of the choice in such a way as to make the "costs" of elective selection prohibitive.

A second concern is that the remedy arguably ignores discrimination. A court finds that an election scheme violates the Voting Rights Act and the response is to take away voting for the office altogether. Such a plan may appear to avoid, not solve, the problem. But a districting scheme that violates $\S 2$ is not necessarily, nor even probably, the result of discrimination. The results test sweeps far more broadly, reaching plans that result in dilution for whatever reason. Further, the state has the right to decide how it will select its judges. While it is certainly true that if elections are used, they must conform to the dictates of the Voting Rights Act, judicial elections are not and cannot be required by the federal government consistent with federalism.

In addition, any initial displeasure with the change will dissipate when and if appointment succeeds in diversifying the bench. To the extent that this cost exists, then, it is temporary. This, of course, will require state politicans adopting this course of action to eschew myopic concerns and focus on the long run. Again, the officials responsible for judicial selection will be elected by means consistent with the Voting Rights Act. If the appointive system 
does not achieve diversity as well as anticipated, there is always recourse to the democratic process to speed up progress. Finally, were the system to fail completely, elections always remain an option. However, to the extent that the relative costs of the two systems can be determined ex ante, it seems that the appointive system will achieve the goals of the Act and minimize the costs of electing judges in general and $\S 2$ remedial districting plans in particular.

Two more brief points must be mentioned. First, there may be a complication if the jurisdiction at issue is covered under $\S 5$ of the Act. In that case, all changes, including a return to appointment, ${ }^{124}$ must be precleared. Therefore, implementation of the appointment remedy will have to overcome an additional hurdle. This hurdle may be so significant that many covered jurisdictions will not be able to return to appointment on their own decision or in response to a $\S 2$ lawsuit. However, denying a state its right to select its judiciary by appointment presents severe problems of federalism. In any event, this would be an extremely important, and perhaps prohibitive, consideration for jurisdictions covered under $\S 5$.

The second concern is with the jurisdiction that is found to have violated $\S 2$, but refuses to offer an acceptable remedial plan. In that case, the court would have to draft a remedy. It would be improper, again for reasons of federalism, for a federal court to force a state to change to an appointive system. A court in this position would simply have to implement the usual safe subdistrict remedial plan. This Comment advocates a policy choice that makes sense given the circumstances, but it is a decision that can be made only by the states themselves. It can neither be made for them nor taken away from them. A state that refuses to offer a proper remedy for a $\S 2$ violation will incur all of the costs inherent in the subdistrict remedy, but it will have made its own bed.

\section{ConCLUSION}

The plain language, structure, and statutory purpose of $\S 2$ of the Voting Rights Act applies to judicial elections; the one person, one vote cases do not refute this analysis. But the application of $\S 2$ presents unique remedial difficulties. This Comment has sketched out some of the problems that arise when the safe subdistrict plan is employed in judicial election cases. The subdistrict 
remedy may serve only to intensify the negative aspects of popular election, which undermine the effectiveness and independence of the judiciary. States faced with the remedial decision should implement an appointive system of judicial selection. If designed and implemented properly, appointment will achieve the goals of the Voting Rights Act and avoid the costs of subdistricting that threaten to destroy the legitimacy of the judicial branch of state government. 
